Succession Narratives in Family Business: The Case of Alessi

\author{
Elena Dalpiaz \\ Imperial College Business School \\ Imperial College London \\ South Kensington Campus \\ London, UK SW7 2AZ \\ Tel: +442075941969 \\ E-mail: e.dalpiaz@imperial.ac.uk \\ Paul Tracey \\ Judge Business School \\ University of Cambridge \\ Trumpington $\mathrm{St}$ \\ Cambridge, UK CB1 1AG \\ Tel: +44 1223760471 \\ E-mail: p.tracey@jbs.cam.ac.uk \\ Nelson Phillips \\ Imperial College Business School \\ Imperial College London \\ South Kensington Campus \\ London, UK SW7 2AZ \\ Tel: +44 2075941699 \\ E-mail: n.phillips@imperial.ac.uk
}




\section{SUCCESSION NARRATIVES IN FAMILY BUSINESS: THE CASE OF ALESSI}

One of the most significant challenges facing family firms is how to successfully manage succession from one generation of leaders to the next. In this paper, we contribute to existing understandings of this complex and difficult process by exploring how successors use family business succession narratives to legitimate their succession. Building on a case study of Alessi, a family-owned Italian design firm, we draw on the literature on organizational narratives to develop a framework for understanding family business succession narratives and present a typology of some of the narrative strategies that can be used during succession. We conclude with a discussion of the theoretical and practical ramifications of a narrative view of succession in family firms. 


\section{INTRODUCTION}

In family businesses, transitions of managerial control from one generation to the next pose significant challenges and often "simply do not work out" (Miller, Steier, \& Le BretonMiller, 2003, p. 513). Thus, the switch between generations represents a time when family firms are especially vulnerable (Handler \& Kram, 2004), and many family firms struggle to survive beyond the first generation. Family business researchers have long recognized these difficulties, and a growing body of research has explored this process and the factors that underpin effective and ineffective succession.

While this work has provided considerable insight into succession in family firms, it has generally used frameworks anchored in economics such as agency theory (Lubatkin, Schulze, Ling, \& Dino, 2005), the resource-based view of the firm (RBV) (Cabrera-Suárez, De Saá-Pérez, \& García-Almeida, 2001), and theories of intention and strategic planning (Sharma, Chrisman, \& Chua, 2004). As a result, we have only a partial understanding of family business succession, and one that neglects, in particular, the role of language and meaning in the family business succession processes.

In this paper, we seek to build on calls (e.g., Steier, 2007) for researchers to take language and meaning more seriously in the study of family firms by considering the role of narratives in the succession process. Narratives are accounts of events - oral, written or filmed - which are told to convey meaning (Barry \& Elmes, 1997; Smith, 2000). More specifically, narratives are complex social artefacts that constitute "storylike constructions containing description, interpretation, emotion, expectations, and related material" (Harvey, 1995, p. 3). Social scientists have taken particular interest in narratives because they are commonly used in attempts to influence how others understand the actions, events, or processes described in the stories (Barry \& Elmes, 1997). 
Narratives play an especially crucial role during family business succession (Dawson \& Hjorth, 2012). This is a time when the meaning of family, the eligibility of the prospective head, and the appropriateness of appointing from within all come under scrutiny (De Massis, Chua, \& Chrisman, 2008). Narratives have the potential to help family members make sense of this complex and challenging situation. Yet, surprisingly, few family business researchers have considered succession in this way. Indeed, Dawson and Hjorth (2012, p. 350) explicitly note the need for more research on family business succession that draws on the concept of narrative in order to bring the "relational, dramatic nature of social reality to the fore."

Our aim is to extend the small number of existing studies that have sought to connect narrative and family business research (e.g., Dawson \& Hjorth, 2012; Hamilton, 2006; Steier, 2007) by showing how successors use narratives to legitimate succession in family firms. In addition to providing a framework for understanding this process, we present a typology of narrative strategies that can be deployed to manage the process effectively. To do so, we draw on an in-depth case study of succession at Alessi, a medium-sized, Italian family firm founded in 1921. Our period of interest begins in 1970 when a new family member - Alberto Alessi - joined the firm and the succession process began. This is a particularly good context to study succession narratives as Alberto extensively constructed his actions and decisions in narratives recorded in a number of in-house publications. We are able to draw on these narrative archives in our study to understand the period of transition, beginning as he prepared the ground for his succession, and then following his succession as he worked to make sense of it for the firm and its stakeholders.

In developing our arguments we make three contributions. First, we extend the application of the concept of narrative within the literature on family business succession, which to date has largely ignored the strategic use of narrative in the succession process. In doing so, we highlight the usefulness of this approach and the insights it is capable of 
generating. Second, we identify some of the specific narrative strategies that family business successors use to legitimate themselves and their actions. The typology we develop provides significant insight into the sorts of strategies that successors can employ and has both theoretical and practical relevance. Third, we discuss the novel and important connection between succession narratives, the construction of the individual identity of the successor, and the reconstruction of the organizational identity of the family firm.

\section{THEORETICAL CONTEXT}

\section{Succession in Family Firms}

Succession is a problem in all firms. However, succession in family business has been found to be different from non-family business in important ways. In particular, research on executive succession in non-family firms has shown that the process often involves a period of adjustment in which the successor seeks to undermine the predecessor in order to augment her or his own legitimacy and to establish a clean break from the past (Ashcraft, 1999;

Gephart, 1991). By contrast, successors in family firms need to construct a vision of the future that is consistent with, and generally complementary to, the legacy of previous generations of family leaders (Poza \& Messer, 2001). As a result, family business succession is a complex and often lengthy process that involves "the actions, events and developments that affect the transfer of managerial control" among family members (De Massis et al., 2008, p. 184).

Moreover, because family business leaders do not generally compete with external candidates for their positions, there may be a presumption of nepotism and a sense among the non-family members of the firm that the successor has not been appointed on merit. This is despite evidence that nepotism may have clear economic advantages because of the knowledge and cultural synergies that exist within families (Bellow, 2004; Lee, Lim, \& Lim, 2003). The upshot is that, "in matters of succession, a challenge for family businesses is to 
avoid the dangers of nepotism while attempting to capitalize on its potential advantages" (Steier \& Miller, 2010, p. 146).

Perhaps because of these distinctive and interesting challenges, succession is one of the most important topics in family business studies. Indeed, Sharma et al. (2004) noted that fully one third of the family business literature focuses on succession. Much of the scholarship to date has considered the factors that facilitate or impede the transfer of power from one generation of family members to the next (De Massis et al., 2008; Le Breton-Miller, Miller, \& Steier, 2004). A number of authors have also examined the micro level, focusing on how intra-family relationships, as well as specific characteristics of successor and/or incumbent CEOs, influence the effectiveness of the succession process (e.g., Lubatkin et al., 2005; Sharma et al., 2004; Sharma, Chrisman, Pablo, \& Chua, 2001).

Other studies have focused on processual factors. This work suggests that effective succession is a function of how the succession process itself is organized (Barach \& Ganitsky, 1995; Handler \& Kram, 2004; Lansberg, 1999). For example, Dyck, Mauws, Starke and Mischke (2002) compare family business succession to a relay race and argue that the succession process is comprised of a series of discrete elements - sequence, timing, technique and communication - involving multiple actors and carried out over extended periods. Finally, some of the literature examines the role of organizational and contextual factors. For example, a change in the performance of the business (Sharma et al., 2001), the cultural context in which the business is located (Le Breton-Miller et al., 2004), or the loss of an important customer or supplier (Lansberg, 1999) may have a significant bearing on succession.

While the work discussed above has provided significant insight into family business succession, it is rooted mostly in what Sarasvathy (2001) terms a "causation" approach. From this perspective, the creation and evolution of successful family ventures is a linear and 
strategic process in which the family develops a particular set of goals and embarks on a course of action designed to achieve them. These goals may not be rational in a purely economic sense, because family firms often prioritize family and other non-economic goals over and above commercial ones, but concepts such as planning (Lansberg \& Astrachan, 1994), intentionality (Brockhaus, 2004), and resource acquisition (Westhead, Howorth, \& Cowling, 2002) feature prominently, and constitute the building blocks of this approach. Agency theory remains the dominant theoretical paradigm used in this work, while the resource-based view of the firm and related approaches in strategic management have also gained increasing traction.

But succession is not only about rationality. Language and meaning also play an important role. We therefore need to attend to these if we are to have a more balanced understanding of family business succession. We propose to use narrative analysis in order to understand succession in family business as partially constituted through language. In doing so we adopt a social constructionist perspective in order to explore how actors convey understanding about the succession process, rather than consider causal relationships between variables.

\section{Narrative and Family Business}

Narrative has been conceptualized in a number of different ways, but we follow Barry and Elmes (1997, p. 431) in defining it as "thematic, sequenced accounts that convey meaning from implied author to implied reader." From this perspective, narrative is a strategic device - a set of carefully constructed stories - that organizational actors use to influence the understanding of others with respect to a particular person, event, or potential future (cf. Sonenshein, 2010). Thus narrative is a key mechanism that can be used for the critical purpose of "meaning-making” (Boje, 1995). 
The notion of narrative is increasingly common in the entrepreneurship literature. Most notably, a great deal of work has been done exploring how narratives enable entrepreneurs to convey their identity to multiple audiences, thereby attracting critical resources to their venture and facilitating their capacity to grow (Navis \& Glynn, 2011). For example, Wry, Lounsbury, and Glynn (2011) highlight two basic types of narratives that nascent entrepreneurial groups use to legitimate their ventures. One is an identity story, which labels and confers meaning on their collective identity. The other is a growth story, which helps to coordinate the group and guides behavior in order to promote expansion. In developing these stories, entrepreneurs use narratives in a highly strategic way, often designed to communicate multiple and sometimes contradictory messages to different groups (Zilber, 2007). Moreover, entrepreneurial narratives are continually refined and adjusted over time; they are inevitably "told in a particular context, to particular listeners, by a particular story teller, for particular purposes" (Gartner, 2007, p. 614). As such, the stories communicated by entrepreneurs are never completed, and are influenced and framed by other ideas, stories and myths.

An emerging interest in narrative is also evident in the family business literature. For example, Hamilton (2006) draws on narrative accounts of new venture creation in three family businesses. Her analysis shows that family firms are often characterized by hidden struggles for power and influence between men and women, and that the role of women is often contested, downplayed and undermined. In another important paper, Steier (2007) used a case study of a technology firm to identify an important "familial sub-narrative" that is often overlooked in conventional analyses of new venture creation. And particularly relevant in the context of our study, Dawson and Hjorth (2012) used narrative analysis to explore five core themes that emerged from a story of a family business that experienced an unsuccessful succession process: leadership style; trust and communication; the "balance" between the 
interests of the business, the family, and individual family members; a concern with the history and identity of the venture; and the fear of a loss of power on the part of individuals. The authors argue that their findings reveal "the multifaceted and complex social constructs that are performed by different actors" during family business succession (p. 339).

In this paper we seek to extend this exciting but still underdeveloped body of work on narrative in the context of family business. In particular, rather than consider the analysis of narratives as an interesting method through which to uncover novel insights about family firms, we conceptualize narratives as a strategic device in family firms. More specifically, we seek to answer the following research question: How do successors use narratives strategically to manage the succession process?

\section{METHOD}

\section{Context}

In order to address our research question, we studied the intriguing case of succession at Alessi, a family owned Italian design and manufacturing firm located in the north of Italy. Our case began in 1970, the point at which a new family member, Alberto Alessi, joined the business. In our study, we focus on his succession over a number of years and the actions that he implemented.

Alessi was founded by Giovanni Alessi in 1921. The firm began as a lathe-work factory and foundry for the production of metal household goods. One of Giovanni's sons, Carlo, joined the family firm in 1932 as a designer and took the helm in the early 1950s. Carlo's appointment as CEO marked a period of international expansion and growth. His younger brother, Ettore, joined the firm in 1945 as head of the technical department. Ettore expanded Alessi's presence in the hospitality market and initiated collaborations with external designers on a few projects for this market. By the early 1970s, Alessi was a 
profitable producer of steel kitchenware and tableware for the hospitality sector and was renowned for the quality of its products.

In July 1970, one of Carlo's sons, Alberto, joined the firm with responsibility for new product development. This article is concerned with Alberto's narrative construction of his succession. Alberto's early initiatives to combine art and industrial manufacturing set the firm off in new direction. Since then, Alberto has engaged in many such initiatives through collaborations with art critics as advisors and artists as designers. He expanded Alessi's production of kitchenware and tableware, began producing other categories of household and personal objects (such as bathroom and living room objects, watches etc.), and experimented with new materials such as plastic, wood and glass.

Over the years, Alessi became recognized internationally as a cultural producer (Gabra-Liddell, 1998; Sweet, 1998) and design powerhouse (Salvato, 2009). Its vision changed from the design and manufacture of household utensils to the production of household objects as art, designed to stimulate an emotional response from consumers (Rindova, Dalpiaz, \& Ravasi, 2011). Through this transformation, Alessi experienced steady growth and profitability above the industry average (Salvato, 2006) and hundreds of its products are now part of the permanent collections of design and modern art museums around the world. Alberto engaged Alessi in a new form of innovation, one based on cultural meanings rather than enhanced functionality or technical improvements (Dell'Era, Marchesi, \& Verganti, 2008).

In order to plan, document, explain and communicate his role as successor and his vision for Alessi, Alberto engaged in intense narrative activity beginning in 1979. The resulting corpus of work contains a rich narrative of Alberto's construction of his actions, thoughts, justifications, and relationship with the cultural field, and as such provides a powerful perspective on his succession. While recognizing that Alberto devised several 
strategies during this period (Rindova et al., 2011), in this paper we argue that Alberto's strategic construction of a family firm succession narrative was pivotal.

In sum, over time Alberto Alessi took control of the family firm and radically transformed the firm's vision as well as its activities and market position. At least initially, it was arguably the distinctive nature of family firm governance (cf. Carney, 2005) that enabled him to experiment even in the face of failure: successors in non-family firms are rarely accorded the opportunity to fail. However, Alberto nonetheless faced pressure to legitimate his role in the eyes of family members; pressure that was exacerbated by another distinctive feature of family governance: his acquisition of firm control without external competition. For these reasons that are peculiar to family firms, and because family-firms are distinguished from non-family firms by the involvement of family members "who shape and pursue the vision" of the firm (Chua, Chrisman, \& Sharma, 1999, 24), we believe that the narrative construction of Alberto's succession in Alessi is an intriguing case that offers a fascinating context in which to explore our research question.

\section{Data Collection}

We drew on three sources of data: Alessi's corporate archive, third-party documents about Alessi, and Alessi official autobiographies (see Table 1 for details on each data source and its use in the analysis).

---Insert Table 1 about here---

The Alessi official autobiographies represent our main source of data to understand Alberto Alessi's narrative of his succession. These books were published at the end of each decade from the point at which Alberto joined the family firm in 1970-i.e. in 1979, 1989, 1998, and 2010 - a total of 718 pages of text and figures. We refer to these books with an alphabetical code, from A to D respectively (see Table 2 for details and a brief summary of the content of the books). 
We selected these books for two reasons. First, they contain text written by Alberto and key actors he collaborated with (e.g. cultural consultants, designers, etc.) on the family firm's history and the actions that Alberto implemented. Because Alberto himself commissioned these books, the contributors' accounts contained within them offer a composite narrative of Alberto's attempts to shape the interpretation of his succession process within Alessi.

Second, while the book published in 1979 marked the beginning of Alessi's editorial activity, the subsequent books quoted or referred to text contained in other documents reporting Alberto's perspective on product development, events, and encounters that marked his succession. As such, these books offer a continuous set of accounts that provide a comprehensive summary of Alberto's narratives that favor a shared understanding of his succession.

\section{Data Analysis}

We undertook the analysis of our data in three steps. First, because the analysis of narratives requires a rich understanding of the context in which narratives are produced (Hardy, Palmer, \& Phillips, 2000), we sought to develop a thorough understanding of the family firm. To do so, we read through data in sources I and II (see Table 1) and developed a thick chronological description of the history of Alessi in which we identified key actors and events (Ventresca \& Mohr, 2002).

Second, we sought a deeper understanding of the involvement of family members in the management of Alessi since it was founded, focusing on sources I and II. For example, we tracked the entry of family members into managerial positions, the new products they championed, and the strategic choices they implemented. This step enabled us to identify Alberto as the latest successor at Alessi, and 1970 as the year in which the process began. 
Finally, we analyzed Alberto's succession narratives using source III. To do so we adopted a functional approach to narrative analysis (Bruner, 1990), which is concerned with uncovering the meanings of particular stories rather than their grammar or their relation to the broader socio-cultural context. Using paragraphs and sentences as coding units, we performed a thematic analysis of the text. Thematic analysis entails searching for themes that meaningfully describe the essence of the narrative (Riessman, 1993).

We proceeded with thematic analysis in three stages. First, we read the data and developed inductive codes that captured the storylines that Alberto used to construct his actions and the family firm's history. These codes, that we call first-order themes, are grounded in our data. Second, we developed more abstract codes by aggregating first-order themes characterized by related storylines into higher-order themes. We refer to these second-order themes as narrative tactics, as they represent a generic storyline chosen by the successor in order to describe a given aspect of the succession process. Third, we realized that groups of narrative tactics appeared to be designed to achieve a specific objective in legitimating succession. We therefore developed a more abstract classification of the data to capture this. Specifically, we grouped the second-order themes into overarching themes that represent generalizable narrative strategies. We view these narrative strategies as overarching approaches to legitimate the succession process. Figure 1 summarizes our analysis.

---Insert Figure 1 about here---

\section{FINDINGS}

Our observations reveal that Alberto used three main narrative strategies to legitimate his succession: constructing sense of family, family eulogizing, and highlighting non-family endorsement. Table 3 offers a summary description of these strategies and their rationale. A key insight from our findings is that the successor's narrative construction of the succession 
includes both the legitimation of 1) the successor as a person and 2) the actions that he or she champions. This involves framing the successor and the new strategy in the context of the past, the present, and the future of the family firm.

---Insert Table 3 about here---

\section{Constructing a Sense of Family}

The first narrative strategy we identified is constructing a sense of family. This involves conveying the idea that the successor is connected to other family members who have held controlling positions in the family firm. Specifically, it entails two tactics: successors linking their actions and decisions to their predecessors, and successors showing that they are emotionally tied to other family members. We discuss each in turn.

\section{Linking Successors' Actions to Predecessors}

This tactic involves successors highlighting how their actions and decisions are rooted in the actions and decisions of their predecessors. For example, with regard to our case, the attention to product aesthetics and to the relationship with societal culture that Alberto championed is ascribed also to Alberto's father Carlo. The Bombé coffee set that Carlo Alessi designed in 1945 is described as having "a strong visual impact" and as being "of noteworthy aesthetic value" (A, p. 71). Yet, Alberto subtly distinguishes Carlo's attention to aesthetics from his own, and defines the former as more oriented to functionality.

An entire book is aimed at explaining the relationship between the strategic direction championed by Alberto with the decisions made by previous family members. For example, Book $\mathrm{C}$ contains the following:

[T]he tale of how a deep-rooted, hard, traditional and perhaps even inward looking manufacturing tradition has blossomed into our own business venture, on the contrary characterized by constant innovation, open to experimentation and to the paradoxical results of casting from a poetic mould. How Alessi has changed from being a "Workshop for the working of brass and nickel silver plates, with foundry (so read the sign over our stand at the first Milan Trade Fair in the twenties) into one of the "Factories of Italian design" (p. 7). 
Another example is the description of Alberto's uncle Ettore's activities. Specifically, it is emphasized in Book C that Ettore "opened up Alessi to collaborations with external designers" (p. 14) in order to improve the functionality of the utensils it produced. Alberto markedly extended collaborations with external designers beyond the one-off initiative pioneered by his Uncle with a view to reframing the production of household objects as applied art.

\section{Displaying Emotional Ties with Family Members}

The second tactic that formed part of the constructing sense of family strategy involves successors highlighting their affective connections with other members of the family. For example, a chapter on the first two decades of Alessi's existence (1920s and 1930s) narrates the activities and achievements of "Grandpa Giovanni” (C, p. 8). Alberto gives the reader special insight into the family when he says about his father that "I have never understood why" he gave up completely on designing when he "took over from Grandpa at the helm of the company" (C, p. 12).

Other references displaying emotional ties to the family are interspersed in the narrative. For example, a plethora of historical pictures representing family members individually or in groups are presented and discussed. These pictures capture the Alessi family in private moments (e.g. drinking coffee at the kitchen table, hiking, etc.) as well as in the factory premises. Alberto also refers to other family members who had a less pivotal role in the family firm than his grandfather, father and uncle. For example, Alberto included pictures and drawings of "my cousin Stefano's house" (C, p. 56) that was designed by Aldo Rossi.

Overall, the strategy of constructing a sense of family highlights the successor as a link in a chain of family members who have previously held senior positions in the business and as an innovator who remains rooted in family traditions. On the one hand, the successor 
construes him/herself as an innovator as well as a caretaker of family traditions, rather than as a revolutionary figure in the firm who does everything anew and on his/her own. On the other hand, the strategic references to the actions of ancestors and relatives, as well as the warm tone of such references, underscore that the successor greatly values his or her family ties and family history.

In sum, the strategy of constructing a sense of family aims at establishing the successor as a legitimate and welcome successor through highlighting aspects such as continuity with family traditions and values, as well as belonging to family - aspects that particularly resonate with family members in family firms (Berrone, Cruz, Gomez-Mejia, \& Larraza-Kintana, 2010). This enhances the perception of the successor's fit with the family, and the esteem in which he or she is held.

\section{Family Eulogizing}

The second strategy that we identified from our analysis is family eulogizing. This refers to the praise that the successor bestows on certain products associated with the particular family members who championed them. By doing so, the successor portrays the family, and specific family members, in a very positive light. This strategy comprises two tactics: constructing emblematic products championed by family predecessors, and constructing emblematic products championed by the successor.

\section{Constructing Emblematic Products Championed by Family Predecessors}

This tactic focuses on products that the successor considered central to the identity and history of the family firm prior to the successor's reign. Of the 650 products analysed in Book A, some are explained at length in separate chapters. For example, the Bombé coffee set designed by Carlo Alessi has its own chapter and it is referred to as the "symbol of Alessi's production history" (A, p. 73), “a phenomenon of costume and design” (A, p. 71), a 
"symbol of the social objectives of the Alessis" (B, p. 32), and "the archetype of early Italian design" (C, p. 12).

Another example is offered by the "citrus basket" designed in 1952 by the Alessi Technical Office under the leadership of Ettore, which "symbolizes our fifties production" $(\mathrm{C}, 14)$. Alessi miniaturised this and other products that it considered emblematic of the identity and history of the family firm. This is exemplified in the following quotation:

The value of the icons. Miniature citrus basket in 18/10 stainless steel. It's a tribute to the stainless steel wire citrus basket, that has been produced initially in the 50s and it's still successful nowadays. It's part of the collection launched by the Museo Alessi of miniatures that represent the most eminent and well-known icons in the Alessi Catalogue. (http://www.alessi.com/en/2/4655/miniatures/370-m-miniature-citrusbasket)

\section{Constructing emblematic products championed by the successor}

This tactic focuses on products that the successor considered central to the identity and history of the family firm after the successor was appointed. In Book A, the first project pursued by Alberto, Alessi d'Aprés, has its own chapter. The commercial fiasco that resulted from this project is reframed in a positive light as the first step towards a new product line and vision that moves Alessi out of its traditional field of housewares manufacture and into the cultural field.

The successor's eulogizing is evidenced in particular in Book B, which contains a detailed description of the genesis, development, and outcomes of 20 new product-related initiatives that express innovative practices and conceptualizations of what constitutes organizational success in the applied art that Alberto championed in the 1980s. Hence, even commercial failures, such as the Hot Berta teakettle designed by Philippe Starck, are portrayed in a very positive light as artistic endeavours and emblematic of the identity of the family firm as a cultural producer.

These stories are described in subsequent publications as pertaining to "historical objects" (D, p. 24), or objects that make up the history of the firm. For example, one such 
narrative is the story behind the design and production of Richard Sapper's "Kettle with singing whistle". The narrative identified across the books explains that Sapper wanted to reproduce the sound of the steamers and barges that ply the river Rhine, but that a whistle reproducing such a sound could not be found anywhere, and that the project was stalled for three years until Alessi discovered craftsmen in the Black Forest in Germany who could produce such a whistle. This story is repeated a number of times, with Alberto seeking to emphasize Alessi's adherence to the principle of the primacy of artistic creativity over commercial considerations.

Overall, the narrative strategy of family eulogizing construes some products, and the history behind them, as symbols of the family heritage and evidence of its capacity for innovation (in the Alessi case for new product development). Hence, this strategy shows the people behind these stories (both predecessors and successors) are capable innovators. This helps the successor to build a legacy that is consistent with the legacy of previous generations of family members (cf., Poza \& Messer, 2001). Thus, it is a strategy that promotes and embeds the legitimacy of the successor.

\section{Highlighting Non-family Endorsement}

The final narrative strategy that we observed is highlighting non-family endorsement. This involves telling stories to convey the successor's personal qualities through direct and indirect endorsement by important actors external to the family. This strategy comprises two tactics: emphasizing the external endorsements of the successor's qualities, and directly promoting the successor's personal qualities.

\section{Emphasizing External Endorsement of the Successor's Qualities}

In this tactic, successors portray their qualities by reaching out to salient external actors in the field, and soliciting and reporting positive feedback from them. In our case, actors from the field of cultural production, such as famous designers and critics, describe 
superlative and sometimes surprising or unexpected qualities in Alberto. For example, Mendini claims that it is thanks to Alberto's "intuitions" that the "10 years of Alessi's extraordinary projects could take place", and goes on to state that Alberto is an "ideal interlocutor and provocateur". He also uses several metaphors to underline Alberto's qualities as a maverick and visionary. For example, Alberto is likened to the "Lonely Sparrow" (B, p. 27) in the famous poem by Giacomo Leopardi; he sings and flies alone towards unknown horizons and is "a dreamer of merry seasons and writer of novels on design" (B, p. 27). Mendini also describes Alberto as a cultured and wise person, and explains that he is the artistic engine behind Alessi's new vision and transformation.

Famous designers also identify Alberto as a key person with whom they want to work. For example, Philippe Starck stated that:

I do not work with Alessi, I work with Alberto Alessi.... I like playing with projects, and the outcome is just a contingency. Alberto is a great player, and that is enough for me (B, p. 234).

\section{Promoting the Successor's Own Personal Qualities Indirectly}

This tactic involves the successor highlighting his individual attributes and strengths through his personal connections with key external actors. The existence and depth of these connections serves as a powerful endorsement of the successor's stature. For example, Alberto says that Richard Sapper "has become a real mentor, one of my maestros" (C, p. 23). He describes Achille Castiglioni's personal qualities as only a man who had privileged access to the "maestro" could. For instance, he underlines their close relationship by providing images of familiarity, as evidenced by the following quote: "our best ideas have come to us late in the evening, over a glass of whisky" (C, p. 36). Similarly, of Aldo Rossi, who tragically passed away in a car accident, he says: "I miss him terribly" (C, p. 52). Alberto creates legitimacy for his ideas by associating himself with the ideas of great designers too. For example, Alberto wrote that Philippe Starck "is a living example of my dream... a true 
work of design must move people, convey feelings, bring back memories, surprise, transgress... in sum, it has to be poetic" (C, p. 74).

Overall, the narrative strategy of highlighting non-family endorsement legitimizes successors through the endorsement of actors who are external to the family and can therefore provide a more objective assessment of successors' qualities. Hence, this strategy further augments the desirability and appropriateness of the successor. This is particularly important in family firms where family members are often appointed on the basis of nepotism (Steier \& Miller, 2010). External endorsement by non-family members therefore sends a powerful signal that the successor is legitimate.

\section{DISCUSSION}

Our findings have a number of implications for understanding succession in family business. In this section, we will discuss three implications that we think are of particular importance. First, we will discuss and summarize the implications of our work for understanding how successors use narratives strategically to manage the succession process in family firms. Second, we will discuss the connection between these succession narratives and the organizational identities of the family firms in which they occur. Third, we will discuss how successors' narratives also construct the individual identity of successors in family firms during the process of succession.

\section{Narrative as a Succession Strategy in Family Firms}

We have argued that our understanding of succession in family firms would benefit from a consideration of the role of narrative in the succession process and have presented the results of a case study of the narratives produced around succession in one family firm. Our findings are consistent with broader discussions about the importance of narrative to leaders more generally: "[f]ew tools are as powerful and readily available to the leader as the use of personal and organizational narrative" (Fleming, 2001, p. 35). However, by focusing 
specifically on how family business successors use narratives during succession, we have opened up a new avenue for deepening our understanding of the succession process.

Our findings suggest that the narratives serve two particular functions. First, in our case the successor constructed narratives that worked to make his new strategy for the firm understandable. Narratives thus play a central role in sensemaking in organizations by "creating a coherent shared experience and aligning employees with corporate values by highlighting social conventions and acceptable behaviors" (Cunliffe \& Coupland, 2012, p. 66). During succession, organizational members must make sense of the tremendous changes in leadership and also often in strategic direction. The succession narratives produced by the successor are therefore critical in helping organizational members work through this process.

Second, succession narratives serve to legitimate the successor as a person. While narratives help to make the successor's strategy clear and understandable, this is only the first step. The narratives also serve to articulate why the successor is worthy and legitimate. Although there is a well-developed literature showing that narratives play a central role in the construction of legitimacy in a general sense (Golant \& Sillince, 2007), we have shown that in addition they play an important role in the legitimation of a successor in a family business, and we have outlined specific narrative strategies and tactics for doing so.

Thus, our analysis contributes to the succession literature by emphasizing the complexity of the succession process in family firms, which may unfold over an extended period and involves the legitimation of both actors and actions in the context of the actors and actions of previous generations. At the same time, while our study begins to provide important insight into the role of narratives in family business succession, much more work needs to be done. On the one hand, while our case is revealing, it is only a single case study and additional investigation into the role of narratives in succession will no doubt reveal more complex processes and effects. On the other hand, while we have studied the "winning" 
narratives, it is clear that in many cases different family members champion conflicting narratives and narrative struggles therefore often ensue. How these struggles develop, the effects of these struggles, and why one narrative sticks while another loses out, remain important questions for further research.

\section{Family Business Identity Narratives}

The deployment of specific narrative strategies over time led to the construction of a “family business identity narrative". We define a family business identity narrative as the narrative developed in a family firm that explains and makes sense of the firm's history, current situation, and plans for the future. It is thus a special kind of organizational identity narrative that seeks to make sense of the company and the role of the family within it. As with the identity narratives of any organization (Somers, 1994), family firm identity narratives also frame how organizational constituents make sense of the organization and construe its core attributes.

In contrast to the identity narratives of non-family firms, however, family firm identity narratives frame how organizational constituents make sense of the organization and construe its core attributes in the context of the family and across generations. During succession, this narrative is particularly evident because the successor needs to construct and justify his or her role with respect to previous generations of family members. If the new leader also aims to introduce significant organizational and strategic changes, she or he may need to reconstruct the identity of the firm so that the new strategy appears consistent with previous family leaders' decisions and values.

We argue that this type of narrative is unique to family businesses as non-family businesses do not face the same problem of positioning present actions and future plans in the context of a successor imbued with the family's values and history. This is consistent with other research which has shown that a crucial difference between family firms and non- 
family firms is the desire by family members to preserve the socio-emotional wealth of the family (Berrone et al., 2010; Gómez-Mejía, Haynes, Núñez-Nickel, Jacobson, \& MoyanoFuentes, 2007). Thus we believe that family firm identity narratives play a crucial role during succession because the successor has to show that his or her leadership is consistent with the family's past.

\section{Successors' Identity Narratives}

While much of our discussion so far has focused on the effects of succession narratives on followers, there is another important dynamic that was highlighted in our case. Although this aspect of our discussion is more speculative and requires much more research, we believe that in the process of constructing narratives to explain and legitimate succession among organizational members and other stakeholders, the successor also constitutes his or her identity as a leader. It is not simply that the narratives reveal the leader to organizational members and other stakeholders, but that the successor is actively engaged in constituting their own identity through these narratives. Our case study, and the theoretical observations we have made, therefore has important ramifications for understanding the construction of the successor's conception of his or her self.

The idea that individual identities are constructed through narrative is not, of course, a new one. In fact, there is a significant literature that argues that identities "are constituted through processes of narration" (Rhodes \& Brown, 2005, p. 176). More specifically, through narrative identity work - "social efforts to craft self-narratives that meet a person's identity aims" (Ibarra \& Barbulescu, 2010, p. 137) - individuals produce narratives that embody their identity in profound ways. The successor is therefore actively constructing his or her own identity - crafting self-narratives - that are equally about making sense of their new position and their new role for themselves. 
This means that the narratives produced and the strategies adopted are about more than just sensemaking and legitimation: they involve the successor working out his or her understanding of the new role and their relationship to the family members that preceded them. This dynamic is not one way. While we did not study it here, we would expect that other organizational members would construct both supporting and alternative narratives. The successor must therefore engage and interact with organizational members in order to create a shared sense of what he or she stands for. From this perspective, the challenge of succession in family firms is to narratively co-produce an authentic, legitimate and inspiring identity for the new leader.

This process of the narrative construction of identity points to a significant area of research that we believe has the potential to produce novel insights into succession in family firms. While existing research has shown that it is important during succession to "communicate the identity of the successor to family members" (Motwani, Levenburg, Schwarz, \& Blankson, 2006, p. 485), the complexity of the identity processes that are occurring has received little attention in the family business literature. This is despite the fact that the family business context seems likely to both increase the importance of this aspect of succession and also to make the dynamics of the narrative construction of identity work differently. We therefore encourage researchers interested in succession in family firms to further explore these important identity dynamics.

\section{CONCLUSION}

Succession is one of the most important topics in family business research. Yet family business scholars have arguably adopted too narrow a range of theoretical tools to shed light on this phenomenon. In this paper we have introduced narrative as an alternative way of conceptualizing important aspects of the succession process in family firms. From this perspective, effective family business succession depends on the ability of family business 
successors to legitimate 1) their own position, and 2) the organizational strategies that they implement, through specific narrative strategies and tactics. Importantly, we offer an initial typology of narrative strategies and tactics used by successors in family businesses to legitimate the succession process.

We believe that our findings also show the importance of further expanding the use of a cultural perspective in the study of family firms. Management research more generally has rekindled its interest in how cultural resources are used within organizations (Weber \& Dacin, 2011; see also Morrill, 2008). In particular, the idea that culture represents a "toolkit" (Swidler, 1986) of resources such as stories, symbols etc., available to actors working to shape organizations and their contexts, has gained increasing traction. This stream of cultural analysis is characterized by two core theoretical shifts with respect to how culture is conventionally conceptualized. First, culture is increasingly seen as a source of agency and strategic change rather than simply as a mechanism that shapes and constrains the behavior of individuals and organizations through taken for granted beliefs, norms and practices. Second, there has been a shift from considering the cultural processes inside of specific organizations or groups of organizations to a broader and more fluid conception of culture that incorporates a concern with the strategic communication of cultural practices by organizations, and the evaluation of those practices by external audiences (Hoffman \& Forbes, 2011). Weber and Dacin (2011) describe this as a move away from a narrow focus on "private culture" to a broader consideration of the role of "public culture" and its implications for organizations. The notion of culture is valuable because it helps us to understand how individuals construct meaning, and a fundamental premise of this paper is that family business succession involves the management of meaning. We find it interesting that, with some important exceptions (e.g., Dawson \& Hjorth, 2012; Steier, 2007; Zahra, Hayton, \& Salvato, 2004), the interest in the cultural perspective that has swept through management research in recent 
years has not been reflected in family business research. Indeed, as noted earlier, our reading of the family business literature suggests that it remains rooted firmly in quasi-economic approaches.

While we think that our paper represents an important step forward in family business research, in many ways we only scratch the surface of what is potentially a considerable intellectual project. First, we have looked at one particular set of succession narratives in one particular family firm. While we believe our findings have broader applicability, there is clearly a need to consider the role of different types of narrative in family business succession and to evaluate the consequences of these narratives on the effectiveness of the succession process. Interestingly, Alessi belongs to a cluster of firms in northern Italy, founded in the 1950s and 1960s, that design and make items for the home (Verganti, 2006). Nearly all of these ventures began as family firms, but only a handful have survived, and of these, two have been taken over by venture capital firms and are no longer in family ownership. It would be interesting to know if succession narratives played a role in the successful firms in this cluster, and whether the absence of such narratives played a part in the downfall of the failed firms. In a similar vein, it would be interesting to explore whether successors in different types of family firms adopt different narrative strategies and tactics to legitimate the succession process. For example, might the succession narratives of dynastic family firms that have maintained power over several generations be dissimilar from those invoked by family businesses that are transitioning from the first to the second generation of family members?

Second, our case also highlights the role and potential of history and tradition in family business succession narratives. Work in organization theory has shown that history may be a source of competitive advantage, with some firms able to access resources because of how they construct their past (Suddaby, Foster, \& Trank, 2010). In a similar vein, our 
findings suggest that history may have an "interpretive function" that is used by family members to frame and legitimate action. Indeed, the role of history and tradition may be especially important in family business succession because of the delicate balance that leaders are required to strike between linking to the past and respecting the achievements of older generations of family members, while at the same time mapping out a distinctive strategy for the future. While we believe our paper represents an important first step in examining the use of history and tradition as cultural tools to manage the succession process, there is still much work to be done. Additional research that explores more fully the role of history in family business succession would make a significant contribution to this gap.

Finally, while we believe our findings have general applicability, we do not claim that the narrative strategies that we have identified represent an exhaustive list or that they will apply in all cases. Indeed, we are very sensitive to the fact that we need to be cautious about generalizing from a single case study and we believe that further research is needed to more fully understand how narratives influence family firm succession. We therefore look forward to other researchers in the family business community extending and refining our analysis. 
Table 1: Data Sources and Use in the Analysis

\begin{tabular}{|c|c|c|}
\hline Source & Details & Use in the Analysis \\
\hline \multirow[t]{2}{*}{$\begin{array}{l}\text { I. Alessi's corporate } \\
\text { archive }\end{array}$} & $\begin{array}{l}\text { - Official autobiographies of Alessi } \\
\text { (4) } \\
\text { - Books on Alessi's product-related } \\
\text { initiatives (16) } \\
\text { - Alberto's speeches to sales force } \\
\text { (2) }\end{array}$ & $\begin{array}{l}\text { Understand succession in } \\
\text { Alessi since founding and } \\
\text { Alberto's succession through } \\
\text { analyzing data about: a) } \\
\text { history of family firm since } \\
\text { founding; b) involvement of } \\
\text { family members in the } \\
\text { management of the firm; c) } \\
\text { dates and facts about the } \\
\text { changes that Alberto triggered } \\
\text { and guided over the years; d) } \\
\text { recognition of Alberto's role } \\
\text { by other organizational } \\
\text { members } \\
\text { Identify the repositories of the } \\
\text { successor's own narrative of } \\
\text { the succession process (see } \\
\text { source III) }\end{array}$ \\
\hline & $\begin{array}{l}\text { - Book on Italian design edited by } \\
\text { Alberto Alessi for the Triennale } \\
\text { Museum (1) } \\
\text { - Books on the relationship } \\
\text { between Alberto Alessi and given } \\
\text { designers (4) } \\
\text { - Italian and American household } \\
\text { magazines (various issues in the } \\
\text { 1980s and 1990s) }\end{array}$ & $\begin{array}{l}\text { Triangulate facts and } \\
\text { observations about Alberto as } \\
\text { successor in the family firm } \\
\text { through analyzing evidence of } \\
\text { external recognition of } \\
\text { Alberto's role in the family } \\
\text { firm over time }\end{array}$ \\
\hline $\begin{array}{l}\text { II. Third-party } \\
\text { documents about } \\
\text { Alessi }\end{array}$ & $\begin{array}{l}\text { - Monographs or academic } \\
\text { publications on Alessi written by } \\
\text { art critics, business historians, } \\
\text { design, and management } \\
\text { scholars (9) }\end{array}$ & $\begin{array}{l}\text { Triangulate facts and } \\
\text { observations about Alberto's } \\
\text { succession through analyzing } \\
\text { evidence of external } \\
\text { recognition of his role in the } \\
\text { family firm over time }\end{array}$ \\
\hline $\begin{array}{l}\text { III. Alessi official } \\
\text { auto-biographies }\end{array}$ & $\begin{array}{l}\text { - Firm's official autobiographies } \\
\text { published at different points in } \\
\text { time and written or championed } \\
\text { by Alberto to explain the history } \\
\text { of Alessi and how his leadership } \\
\text { changed the firm's strategy over } \\
\text { time (4) } \\
\text {--See Table } 2 \text { for details }\end{array}$ & $\begin{array}{l}\text { Track the successor's } \\
\text { construction of the process of } \\
\text { succession through thematic } \\
\text { analysis of text }\end{array}$ \\
\hline
\end{tabular}


Table 2: Overview of Data Used in Analysis

\begin{tabular}{|c|c|c|c|c|}
\hline $\begin{array}{c}\text { Source } \\
\text { (year) }\end{array}$ & Author/Editor & Occasion & Summary of Content & Pages \\
\hline A (1979) & $\begin{array}{l}\text { Author: Alessandro Mendini (Italian } \\
\text { architect, and editor of design } \\
\text { magazines). From } 1979 \text { he became } \\
\text { Alberto's "cultural consultant". }\end{array}$ & $\begin{array}{l}\text { In the mid-1970s, Alberto commissioned } \\
\text { Mendini an analysis of Alessi production. } \\
\text { The book contains this analysis and } \\
\text { accompanied the first retrospective } \\
\text { exhibition on Alessi, in Milan. }\end{array}$ & $\begin{array}{l}\text { Analysis of Alessi's production from } 1921 \text { to } 1979 \text {, } \\
\text { and planning for new product lines, new functions } \\
\text { (museum), and activities (publishing). These plans } \\
\text { will be later developed under Alberto. }\end{array}$ & 154 \\
\hline B (1989) & $\begin{array}{l}\text { Editor: Laura Polinoro-semiotician } \\
\text { hired by Alberto as head of a multi- } \\
\text { disciplinary research center on the } \\
\text { meaning of household objects. } \\
\text { Authors: Alberto Alessi, Alessandro } \\
\text { Mendini, Laura Polinoro, various } \\
\text { designers, and a museum curator. }\end{array}$ & $\begin{array}{l}\text { Retrospective exhibition on Alessi at the } \\
\text { Centre Pompidou in Paris with a focus on } \\
\text { Alessi's last } 10 \text { years of projects. }\end{array}$ & $\begin{array}{l}\text { Explanation of what type of firm Alessi became } \\
\text { through the activities that Alberto championed since } \\
\text { 1979. Some chapters theorize the new business } \\
\text { model, others report on selected projects for new } \\
\text { product development. }\end{array}$ & 269 \\
\hline C (1998) & Author: Alberto Alessi. & No specific event. & $\begin{array}{l}\text { Alberto's interpretation of his family firm's history, } \\
\text { projects and activities since } 1921 \text { that transformed } \\
\text { Alessi from "a metallurgic and mechanical industry } \\
\text { into a workshop actively researching into the field of } \\
\text { applied arts" (p.7). }\end{array}$ & 124 \\
\hline D (2010) & $\begin{array}{l}\text { Editor: Alessandro Mendini. } \\
\text { Authors: Alberto, Alessandro Mendini, } \\
\text { Chiara Alessi, and a museum curator. }\end{array}$ & $\begin{array}{l}\text { Retrospective exhibition on Alessi at the } \\
\text { International Design Museum in Munich } \\
\text { with a focus on the future. }\end{array}$ & $\begin{array}{l}\text { Alberto's new interpretation of family firm's history } \\
\text { based on construction of partially different phases } \\
\text { from those identified in prior books. }\end{array}$ & 171 \\
\hline
\end{tabular}




\section{Figure 1: Data Structure}

\author{
First-order Themes \\ (Examples from the case)
}

\section{Second-order Themes \\ (Narrative tactics)}

\section{Overarching Themes \\ (Narrative strategies)}

- Tying successor's focus on art-led innovation of products to his father's design ability

- Tying successor's focus on the importance of handicraft to origin of family firm as metal workshop

- Mentioning family members by their title (e.g. "Grandpa Giovanni”, "Uncle Ettore”, "my Dad")

- Referring to various family members

- Presenting old pictures of family members in private moments or in the firm's premises

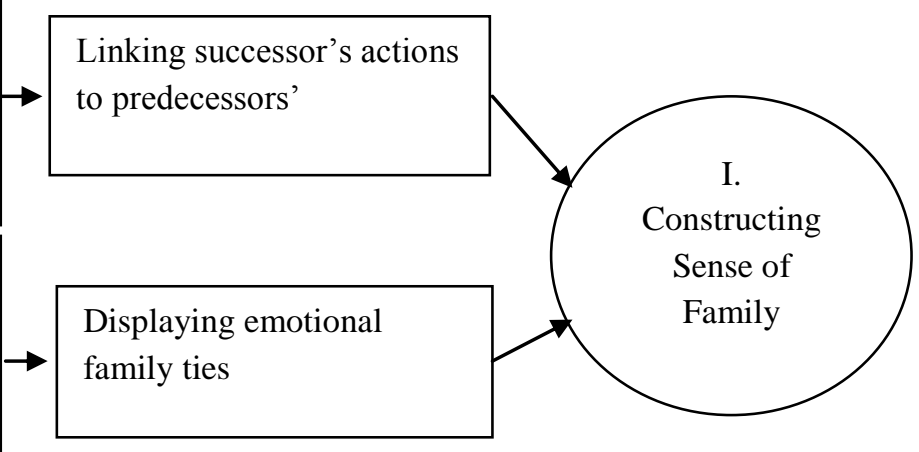

- Telling stories about products defined as emblematic of predecessors' approach (e.g. 870 cocktail shaker championed by Alberto's uncle; 370 citrus basket championed by Alberto's uncle)

- Presenting pictures and drawings of these products

- Producing these products as "miniatures" in the 2000s (observation)

- Stories about numerous products championed by Alberto and defined as emblematic of his approach (e.g. art multiples Alessi d'Aprés, Neapolitan coffee maker, 9091 tea kettle)

- Pictures of these products

- Production of these products as "miniatures" in the 2000s (observation)

- Stories and excerpts from art critics and architects hyping qualities of the successor (e.g. "ideal interlocutor and provocateur", "spiritus rector of Alessi")

- Successor emphasizing his personal connection to famous artists and architects

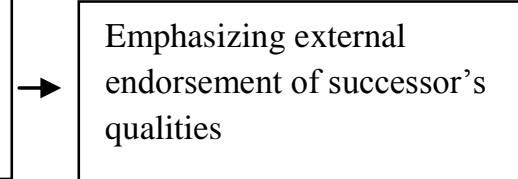

Successor's promoting his/her personal qualities indirectly

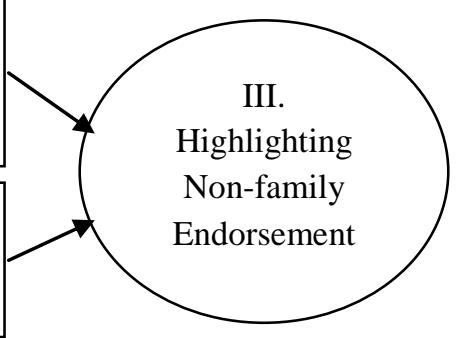


Table 3: Strategies Used in Family Business Succession Narratives

\begin{tabular}{|c|c|c|c|}
\hline $\begin{array}{l}\text { Narrative } \\
\text { Strategies }\end{array}$ & $\begin{array}{c}\text { Constructing Sense of } \\
\text { Family }\end{array}$ & Family Eulogizing & $\begin{array}{c}\text { Highlighting Non-family } \\
\text { Endorsement }\end{array}$ \\
\hline Definition & $\begin{array}{l}\text { Convey the idea that the } \\
\text { successor is connected to, and } \\
\text { value, other family members } \\
\text { who have held controlling } \\
\text { positions in the family firm. }\end{array}$ & $\begin{array}{l}\text { Praise on particular innovations, } \\
\text { actions, events associated with } \\
\text { the particular family members } \\
\text { who championed them. }\end{array}$ & $\begin{array}{l}\text { Convey the successor's } \\
\text { personal qualities through } \\
\text { direct and indirect } \\
\text { endorsement by important } \\
\text { actors external to the family. }\end{array}$ \\
\hline $\begin{array}{l}\text { Narrative } \\
\text { Tactics }\end{array}$ & $\begin{array}{l}\text { - Linking successor's actions } \\
\text { to predecessors' } \\
\text { - Displaying emotional } \\
\text { family ties }\end{array}$ & $\begin{array}{l}\text { - Constructing emblematic } \\
\text { products championed by } \\
\text { family predecessors } \\
\text { - Constructing emblematic } \\
\text { products championed by the } \\
\text { successor }\end{array}$ & $\begin{array}{l}\text { - Emphasizing external } \\
\text { endorsement of successor's } \\
\text { qualities } \\
\text { - Successor's promoting } \\
\text { his/her own personal } \\
\text { qualities }\end{array}$ \\
\hline \multirow[t]{2}{*}{$\begin{array}{l}\text { Legitimating } \\
\text { Mechanism }\end{array}$} & $\begin{array}{l}\text { Tapping into the family firm's } \\
\text { special need for belonging } \\
\text { and for infusing family } \\
\text { values. }\end{array}$ & $\begin{array}{l}\text { Leveraging family firm's special } \\
\text { need for preserving family } \\
\text { legacy. }\end{array}$ & $\begin{array}{l}\text { Discharging nepotism } \\
\text { presumption. }\end{array}$ \\
\hline & $\begin{array}{l}\text { The references to the actions } \\
\text { of relatives, as well as the } \\
\text { warm tone of such references, } \\
\text { underscore that the successor } \\
\text { greatly values his or her } \\
\text { family ties and family } \\
\text { history. This strategy } \\
\text { therefore establishes the } \\
\text { successor as a welcome } \\
\text { successor. }\end{array}$ & $\begin{array}{l}\text { Construe selected actions, } \\
\text { events, and innovations } \\
\text { undertaken by given family } \\
\text { members (both predecessors and } \\
\text { successors) as symbols of the } \\
\text { family heritage and of its } \\
\text { business capacity. This strategy } \\
\text { therefore builds successor's } \\
\text { legacy that is consistent with the } \\
\text { legacy of previous generations } \\
\text { of family members. }\end{array}$ & $\begin{array}{l}\text { The direct and indirect } \\
\text { endorsement of successor's } \\
\text { desirable qualities by non- } \\
\text { family members certifies the } \\
\text { successor as a capable } \\
\text { individual. This strategy } \\
\text { therefore suggests that the } \\
\text { successor was not chosen for } \\
\text { nepotism but because of his or } \\
\text { her objective capacities. }\end{array}$ \\
\hline
\end{tabular}




\section{References}

Ashcraft, K. L. (1999). Managing maternity leave: A qualitative analysis of temporary executive succession. Administrative Science Quarterly, 44(2), 240-280.

Barach, J. A., \& Ganitsky, J. B. (1995). Successful succession in family business. Family Business Review, 8(2), 131-155.

Barry, D., \& Elmes, M. (1997). Strategy retold: Toward a narrative view of strategic discourse. Academy of Management Review, 22(2), 429-452.

Bellow, A. (2004). In Praise of Nepotism. New York: Doubleday.

Berrone, P., Cruz, C., Gomez-Mejia, L. R., \& Larraza-Kintana, M. (2010). Socioemotional Wealth and Corporate Responses to Institutional Pressures: Do Family-Controlled Firms Pollute Less? Administrative Science Quarterly, 55(1), 82-113.

Boje, D. M. (1995). Stoies of the storytelling organization: A postmodern analysis of Disney as "Tamara-Land". Academy of Management Journal, 38(4), 997-1035.

Brockhaus, R. H. (2004). Family business succession: Suggestions for future research. Family Business Review, 17(2), 165-177.

Bruner, J. S. (1990). Acts of Meaning. Cambridge, MA: Harvard University Press.

Cabrera-Suárez, K., De Saá-Pérez, P., \& García-Almeida, D. (2001). The succession process from a resource-and knowledge-based view of the family firm. Family Business Review, 14(1), 37-46.

Carney, M. (2005). Corporate governance and competitive advantage in family- controlled firms. Entrepreneurship Theory and Practice, 29(3), 249-265.

Chua, J. H., Chrisman, J. J., \& Sharma, P. (1999). Defining the Family Business by Behavior. Entrepreneurship Theory and Practice, 23(4), 19-39.

Cunliffe, A., \& Coupland, C. (2012). From hero to villain to hero: Making experience sensible through embodied narrative sensemaking. Human Relations, 65(1), 63-88.

Dawson, A., \& Hjorth, D. (2012). Advancing family business research through narrative analysis. Family Business Review, 25(3), 339-355.

De Massis, A., Chua, J. H., \& Chrisman, J. J. (2008). Factors preventing intra-family succession. Family Business Review, 21(2), 183-199.

Dell'Era, C., Marchesi, A., \& Verganti, R. (2008). Linguistic network configurations: management of innovation in design-intensive firms. International Journal of Innovation Management, 12(1), 1-19.

Dyck, B., Mauws, M., Starke, F. A., \& Mischke, G. A. (2002). Passing the baton: The importance of sequence, timing, technique and communication in executive succession. Journal of Business Venturing, 17(2), 143-162.

Fisher, G. (2012). Effectuation, causation and bricolage: A behavioral Comparison of emerging theories in entrepreneurship research. Entrepreneurship Theory and Practice, September, 1019-1051.

Fleming, D. (2001). Narrative leadership: Using the power of stories. Strategy \& Leadership, 29(4), 34-36.

Gabra-Liddell, M. (Ed.). (1998). Alessi. The Design Factory (Second ed.). London: WileyAcademy. 
Gartner, W. B. (2007). Entrepreneurial narrative and a science of the imagination. Journal of Business Venturing, 22(5), 613-627.

Gephart, R. P. (1991). Succession sensemaking and organizational change: A story of a deviant college president. Journal of Organizational Change Management, 4(3), 35-44.

Golant, B. D., \& Sillince, J. A. A. (2007). The constitution of organizational legitimacy: A narrative perspective. Organization Studies, 28(8), 1149-1167.

Gómez-Mejía, L. R., Haynes, K. T., Núñez-Nickel, M., Jacobson, K. J. L., \& Moyano-Fuentes, J. (2007). Socioemotional Wealth and Business Risks in Family-controlled Firms: Evidence from Spanish Olive Oil Mills. Administrative Science Quarterly, 52(1), 106-137.

Hamilton, E. (2006). Whose story is it anyway? Narrative accounts of the role of women in founding and establishing family businesses. International Small Business Journal, 24(3), 253-271.

Handler, W. C., \& Kram, K. E. (2004). Succession in family firms: The problem of resistance. Family Business Review, 1(4), 361-381.

Hardy, C., Palmer, I., \& Phillips, N. (2000). Discourse as a strategic resource. Human Relations, 53(9), 1227-1248.

Harvey, J. H. (1995). Acounts. In A. S. R. Manstead \& M. Hewstone (Eds.), The Blackwell Encyclopedia of Social Psychology (pp. 3-5). Oxford: Blackwell.

Hoffman, A. J., \& Forbes, M. (2011). The Culture and Discourse of Climate Skepticism. Strategic Organization 9(1).

Ibarra, H., \& Barbulescu, R. (2010). Identity as narrative: Prevalence, effectiveness, and consequences of narrative identity work in macro work role transitions. Academy of Management Review, 35(1), 135-154.

Lansberg, I. (1999). Succeeding generations: Realizing the dream offamilies in business. Harvard: Harvard Business Press.

Lansberg, I., \& Astrachan, J. H. (1994). Influence of family relationships on succession planning and training: The importance of mediating factors. Family Business Review, 7(1), 39-59.

Le Breton-Miller, I., Miller, D., \& Steier, L. P. (2004). Toward an integrative model of effective FOB succession. Entrepreneurship Theory and Practice, 28(4), 305-328.

Lee, K. S., Lim, G. H., \& Lim, W. S. (2003). Family business succession: Appropriation risk and choice of successor. Academy of Management Review, 28(4), 657-666.

Lubatkin, M. H., Schulze, W. S., Ling, Y., \& Dino, R. N. (2005). The effects of parental altruism on the governance of family-managed firms. Journal of Organizational Behavior, 26(3), 313-330.

Miller, D., Steier, L., \& Le Breton-Miller, I. (2003). Lost in time: Intergenerational succession, change, and failure in family business. Journal of Business Venturing, 18(4), 513-531.

Morrill, C. (2008). Culture and organization theory. The Annals of the American Academy of Political and Social Science, 619(1), 15-40.

Motwani, J., Levenburg, N. M., Schwarz, T. V., \& Blankson, C. (2006). Succession Planning in SMEs An Empirical Analysis. International Small Business Journal, 24(5), 471-495.

Navis, C., \& Glynn, M. A. (2011). Legitimate distinctiveness and the entrepreneurial identity: influence on investor judgments of new venture plausibility. Academy of Management Review, 36(3), 479-499.

Poza, E. J., \& Messer, T. (2001). Spousal leadership and continuity in the family firm. Family Business Review, 14(1), 25-36. 
Rhodes, C., \& Brown, A. D. (2005). Narrative, organizations and research. International Journal of Management Reviews, 7(3), 167-188.

Riessman, C. K. (1993). Narrative Analysis. London: Sage.

Rindova, V., Dalpiaz, E., \& Ravasi, D. (2011). A Cultural Quest: A study of organizational use of cultural resources in strategy formation Organization Science, 22(2), 413-431.

Salvato, C. (2006). Micro-foundations of organizational adaptation. A field study in the evolution of product development capabilities in a design firm. Unpublished doctoral dissertation. Jonkoping International Business School.

Salvato, C. (2009). Capabilities unveiled. The role of ordinary activities in the evolution of product development process. Organization Science, 20(2), 384-409.

Sarasvathy, S. D. (2001). Causation and effectuation: Toward a theoretical shift from economic inevitability to entrepreneurial contingency. Academy of Management Review, 26(2), 243263.

Sharma, P., Chrisman, J. J., \& Chua, J. H. (2004). Succession planning as planned behavior: Some empirical results. Family Business Review, 16(1), 1-15.

Sharma, P., Chrisman, J. J., Pablo, A. L., \& Chua, J. H. (2001). Determinants of initial satisfaction with the succession process in family firms: A conceptual model. Entrepreneurship Theory and Practice, 25(3), 17-36.

Smith, C. P. (2000). Content analysis and narrative analysis. In T. Reis \& C. Judd (Eds.), Handbook of Research Methods in Social and Personality Psychology (pp. 313-335). Cambridge: Cambridge University Press.

Somers, M. R. (1994). The narrative constitution of identity: A relational and network approach. Theory and Society, 23, 605-649.

Sonenshein, S. (2010). We're changing - Or are we? Untangling the role of progressive, regressive, and stability narratives during strategic change implementation. Academy of Management Journal, 53(3), 477-512.

Steier, L. (2007). New venture creation and organization: A familial sub-narrative. Journal of Business Research, 60(10), 1099-1107.

Steier, L., \& Miller, D. (2010). Pre-and post-succession governance philosophies in entrepreneurial family firms. Journal of Family Business Strategy, 1(3), 145-154.

Suddaby, R., Foster, W. M., \& Trank, C. Q. (2010). Rhetorical history as a source of competitive advantage. Advances in Strategic Management, 27, 147-173.

Sweet, F. (1998). Alessi. Art and Poetry. London: Thames and Hudson.

Swidler, A. (1986). Culture in action: symbols and strategies. American Sociological Review, 51(2), 273-286.

Ventresca, M. J., \& Mohr, J. W. (2002). Archival research methods. In J. A. C. Baum (Ed.), The Blackwell Companion to Organizations (pp. 805-828). Oxford: Blackwell.

Verganti, R. (2006). Innovating through design. Harvard Business Review, 84(12), 114-122.

Weber, K., \& Dacin, M. T. (2011). The cultural construction of organizational life: Introduction to the special issue. Organization Science, 22(2), 287.

Westhead, P., Howorth, C., \& Cowling, M. (2002). Ownership and management issues in first generation and multi-generation family firms. Entrepreneurship \& Regional Development, 14(3), 247-269.

Wry, T., Lounsbury, M., \& Glynn, M. A. (2011). Legitimating nascent collective identities: Coordinating cultural entrepreneurship. Organization Science, 22(2), 449-463. 
Zahra, S. A., Hayton, J. C., \& Salvato, C. (2004). Entrepreneurship in family vs. non- family firms: A resource- based analysis of the effect of organizational culture. Entrepreneurship Theory and Practice, 28(4), 363-381.

Zilber, T. B. (2007). Stories and the Discursive Dynamics of Institutional Entrepreneurship: The Case of Israeli High-tech after the Bubble. Organization Studies (01708406), 28(7), 10351054. 